\title{
Case Study: Remixing Knowledge with Layered Intelligences
}

\section{LUCY HG SOLOMON}

Associate Professor, Art, Media, and Design, California State University San Marcos

\section{CESAR BAIO}

Associate Professor, Art and Technology, UNICAMP (Universidade Estadual de Campinas)

\section{CESAR \& LOIS}

Art collective consisting of Lucy HG Solomon and Cesar Baio

\begin{abstract}
The case study of Degenerative Cultures explores how the layering of different forms of logic offers an opportunity for rethinking our human systems and hypothetically remixing the epistemological roots of society - through interventions into our technological systems. In Degenerative Cultures, the living organism Physarum polycephalum partners with an artificial intelligence that compiles and corrupts an archive of human texts. In the iterative art installation, which incorporates the growth cycles of microbiological organisms, protists as well as fungi cover up and effectively remix human texts. Human knowledge, contained within the philosophy books used in the project, becomes the substrate for organic growth. The living organisms grow over an actual book, and the AI, referred to as a "digital fungus," corrupts texts on the Internet. The artists' experiment, which links microbiological growth logic to artificial intelligence, is one step in rethinking how human knowledge may become layered and ultimately corrupted and rerouted - a forking of sorts - through integration with nonhuman logic systems, including microbiological and artificial intelligences. By orienting this work to remix theory, the article offers the hypothesis of a multispecies recombination that could, in utopian terms, reformulate the epistemological basis of modernity. In order to pursue this hypothesis, the art collective Cesar \& Lois asks what role remix plays in the ongoing emergence of artificial intelligence and machine learning.
\end{abstract}

\section{INTRODUCTION}

In this article, the art collective Cesar \& Lois examines the project Degenerative Cultures in light of concepts related to remix culture. In this interactive installation produced and exhibited in different iterations across the globe, living organisms, social networks and artificial intelligence work together to realign the relationship between humanity and nature conveyed in physical and digital texts. The artists appropriate texts published in books that undergird the roots of modern Western societies. What all of the excerpted texts from these books have in common is an articulation of the idea that humans (actually only some select humans) have the right and the 
capacity to control, reshape and dominate the realms of other natural entities and forces. Physarum polycephalum grows across that text, according to its own logic. ${ }^{1}$

Beside the inoculated book, a computer monitor shows an intelligent digital fungus that searches the Internet and corrupts texts with the same predatory intent of the text found in the physical book, as both print and online texts assert human control over nature. A digital interface connects biological and computational organisms in what we consider a "bhiobrid" (biological and digital hybrid) intelligent system. ${ }^{2}$ The digital fungus integrates artificial intelligence and generative algorithms with a Twitter bot, allowing anyone to interact with the system and help destroy the texts.

By networking artificial intelligence, microorganic decision-making, and human logic, the artists create a system that reframes the originally intended meaning of the textual signs written by thinkers from a wide range of areas, and remixes them through a multilayered process. As a result of this process, the artwork generates a sequence of output in which the original ideas sampled from the physical books and texts found online are remixed. The new textual composition is published in the Twitter feed of @ HelloFungus and is printed out continuously on site on a miniature thermal printer.

The artwork creates an intricate system for material sampling, ${ }^{3}$ which physically corrupts texts and changes meanings by redacting textual signs, consuming information and making errors. As explicated in this article, this process occurs in different stages in the installation, mixing different sources of information through recontextualization, juxtaposition, subtraction and addition of texts. The understanding of remix here is not necessarily the same as that given to the term in the context of remixing music, although it adheres to some of the same principles. As postulated by Navas, "principles found in the act of remixing in music become conceptual strategies used in different forms in art, media, and culture." As pointed out by Manovich, remix is connected to the new hybrid language that prevails in digital media, ${ }^{5}$ and it has become a dominant aesthetic emerging in the age of "the cultural logic of networked global capitalism." 6

Decades before the publication of Manovich's insightful text on digital media aesthetics, Vilém Flusser foresaw the potential of computer-based networking in the creation of a kind of dialogue based on the gesture of creative play in media, ${ }^{7}$ accumulated during repeated manipulations of media objects by different networked users. Curiously, Flusser addresses what we consider one of the principles of remix - the creative agency of an individual on media and cultural content produced by others - evoking examples from the field of music. However, instead of talking about dub, for instance, he analyzes chamber music, explaining how the musicians respond to the other musicians in their ensemble and to the music that is in progress: "Each player is both a sender and a receiver of information. His goal is to synthesize new information to become more than the playing." "For Flusser, this would be the essence of what he considered in his time the emerging telematic society: when "I sit at my terminal, receive information in the form of electronic images, and I manipulate them using the keys, changing them and sending them on." From the Jamaican dub and remix practices in current music, from the practices of assemblage and readymade, to the more recent hybrid language, ${ }^{10}$ remix has become a cultural practice that "play[s] a key role in modernism, postmodernism, and new media during the first decade of the twenty-first century." 11

Although Degenerative Cultures was not designed to be a remix, the artists' intentions are aligned with remix culture. Our first intent was to merge nature and AI to create something new from 
samples of texts that materialize those epistemological patterns that we consider to be the roots of the Anthropocene and the associated climate crisis. While Degenerative Culture as an installation does not explicitly represent a remix, the conceptual principles that organize its bhiobrid system and the final output of the installation are closely related to sampling and remixing.

In the following sections we analyze the main aspects that connect Degenerative Cultures to remix as a cultural and artistic practice. It is that remixing of process and logic that prompts a rethinking of how other species and machines think; it is in that composite rethinking and mixing that new thoughts become possible. As Donna Haraway forecasts (when she quotes another), "it matters what ideas we use to think other ideas (with)." ${ }^{\prime 2}$ New possibilities for thinking, and new thoughts arising from those, are possible.

\section{DEGENERATIVE CULTURES: LAYERING HUMAN, NONHUMAN AND ARTIFICIAL INTELLIGENCES}

In Degenerative Cultures, Physarum polycephalum (which is commonly called "slime mold" but is actually a protist) is integrated with an artificial intelligence that also corrupts an archive of human texts. The art installation, in each of its iterations between 2018 and 2020 (in England, Portugal, Singapore and Brazil), incorporates the growth cycles of microbiological organisms: the protists as well as the book-borne fungi (native molds) cover up the text, effectively redacting and ultimately reconstructing it through a process of selective remix. Human knowledge, contained within the philosophy books on display in the installation, becomes the substrate for organic growth. The living organisms grow over an actual book, and the AI, referred to as a "digital fungus," corrupts texts on the Internet.

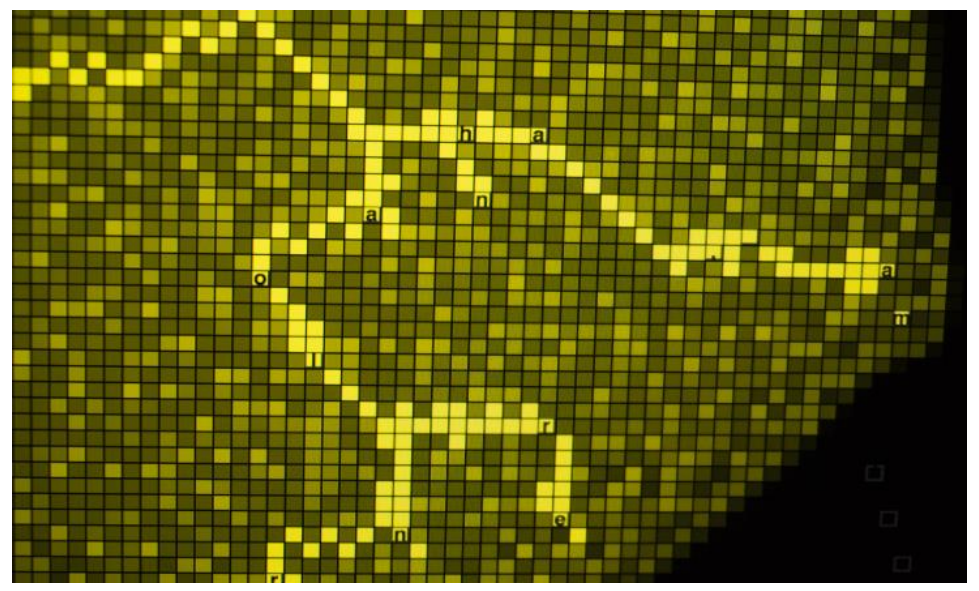

Figure 1. Cesar \& Lois, AI of Degenerative Cultures, Lumen Prize Exhibition, UK, 2018. (Photo: Cesar \& Lois) 


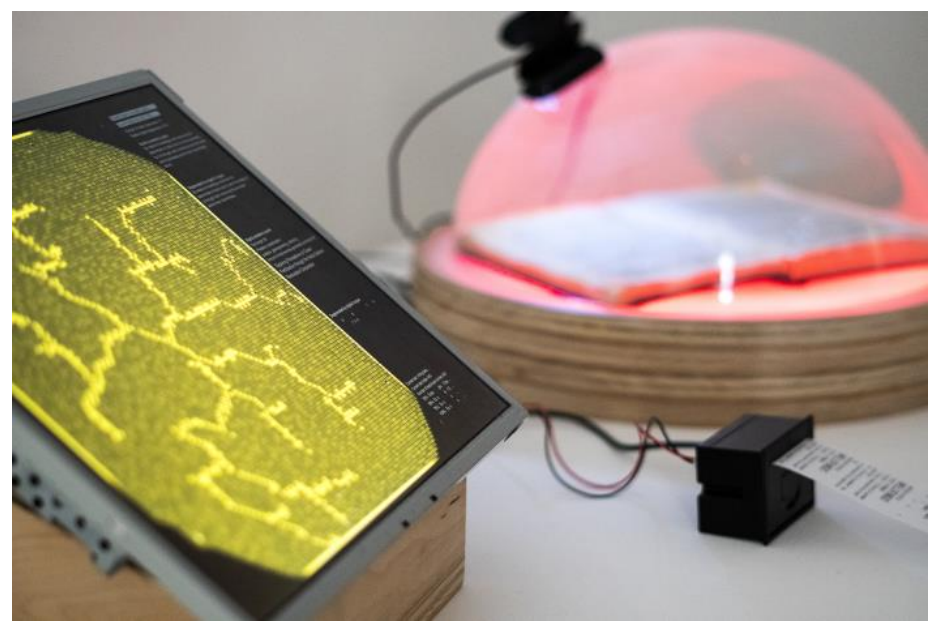

Figure 2. Cesar \& Lois, Degenerative Cultures, Lumen Prize Exhibition, UK, 2018. (Photo: Cesar \& Lois)

\section{Remix As Multispecies Collaboration}

Degenerative Cultures is both an artwork and a prototype for the mixing of different logic systems. The layering of microbiological growth logic over human knowledge interacts with an AI that tweets a degenerated output of the original text, since the microorganisms grow over and effectively reconstruct the meanings of the human text. Within the context of the texts, all mid-twentiethcentury publications of modern philosophy's exaltation of human superiority over the natural world, the entrenched human logic is cut up and reformed, the output generating original texts as Tweets. With the gradual growth of Physarum polycephalum over the text of the book, the stated logic morphs, becoming quite different from the original. In the same way that human knowledge can dictate the parameters for the logic and "growth" of artificial intelligence, the microbiological organisms of Degenerative Cultures are bound by the original text. Yet the outcome-what text remains and constitutes the new text-is reorganized according to microbiological intelligence, an intelligence observed in the measured growth and distribution of resources across the living systems.

As noted by Navas in his analysis of Gilberto Gil's performance of musical covers, ${ }^{13}$ the gesture of remixing is a collaborative action that takes something existing and transforms it into something new based on an individual interpretation. "Remix culture aims to find a balance between the individual and the collective, the creator and audience, creative license and intellectual rights." 14 In Degenerative Cultures, the protist Physarum polycephalum is itself an individual and a collective at the same time, as it has many nuclei (polycephalum is Latin for "multibrain") but it is a single large cell. Consistent with Gilbert Simondon's understanding of the individuation of the technical object, ${ }^{15}$ this microorganism is connected with a computational individual that merges an AI (Natural Language Processing) and generative algorithms to seek texts on the Internet and corrupt them. Human agency in the project is not only present in the artists' gesture of conceiving and putting together the artwork, which includes selecting the part of the book that is sampled and training the AI algorithm, but also in the Twitter user's action of mentioning @ HelloFungus and triggering new searches by the digital fungi. Each of these actions generates the remixing of digital and analog texts. 
In this regard, we can point out that most AIs, specifically the machine learning that is the basis of most current technologies, have some principles of remix embedded within them. In Degenerative Cultures, the "cutting" 16 act is shared between the artist and the AI: for the physical book the artists strategically select a significant author and text in order to focus on a specific excerpt; for the digital consumption the AI is trained by the artists, but acquires a certain autonomy in the choice of the texts that will be consumed.

A primary method of machine learning requires training data that consists of samples of the main category of those things from which the AI is intended to extract patterns. ${ }^{17}$ In order to recognize a dog in a photo, for example, many photos of dogs are collected and used to train the algorithm. If this algorithm is created to make a new image (instead of recognizing something in a photo), as occurs in projects like Google Deep Dreams ${ }^{18}$ and This person does not exist ${ }^{19}$ then these samples become an indirect part of the image projected by the system. Although the original material samples cannot be recognized in the new photo, which pushes it beyond the concept of remix, those sampled images (specifically, the patterns within them) remain crucial.

While it is debatable whether machine learning algorithms are consistent examples of remix, in Degenerative Cultures the AI is the agent of the textual remix process. Trained by the artists to recognize texts that express the idea of overtaking nature, this computational system searches on the Internet to select specific quotes from original textual material and spreads the text's letters on the two-dimensional space of the screen. Each of the letters of the original text represents a virtual source of food to the generative algorithm that starts to grow, seeking to "feed" itself. Each letter reached by one branch of the virtual organism is eaten and disappears from the sampled text. The original meaning of the text fades away, giving way to blank spaces, to nonsense and to new words formed by the remaining letters, with new and poetic phrases created through this process of corruption. As explained in the next section, this process of degenerative remix interacts with the physical text of the book.

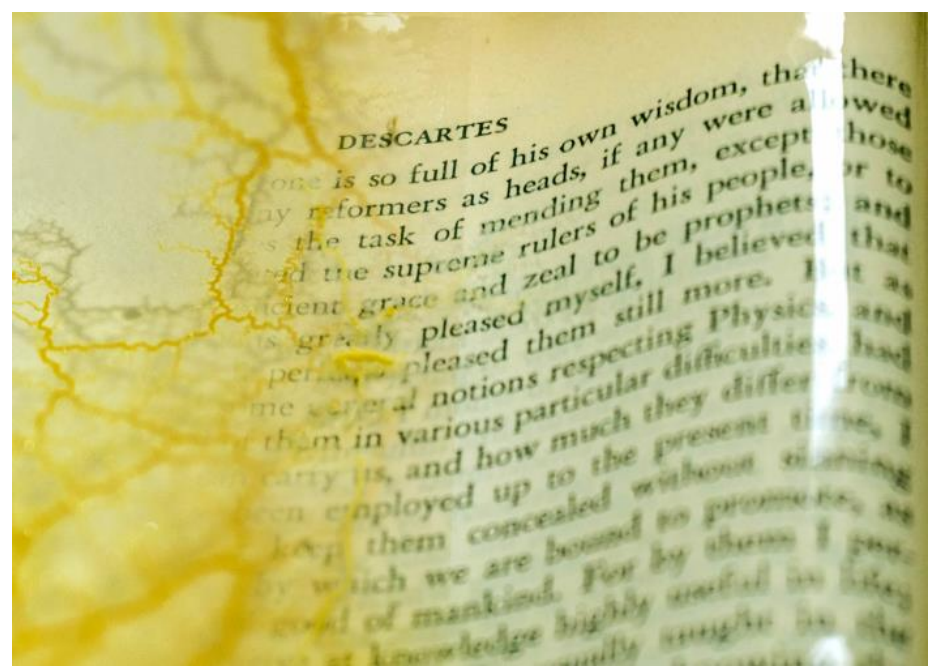

Figure 3. Cesar \& Lois, Degenerative Cultures, Singapore Global Digital Art Prize Biennale, 2019, Microbiological Growth over Text of Descartes. (Photo: Cesar \& Lois) 


\section{Singapore Edition: Remix Principles in Growth over Descartes}

As an example of the performative remixing of the microbiological culture's growth over the pages of The Dream of Descartes in Singapore, the original text reads: "full realization of reason, and he is persuaded that we shall manage through science to subject nature completely, within us and outside of us, to our reason which will then become effectively the queen of nature. On the other hand, reason for him..." ${ }^{20}$ As Physarum polycephalum, the non-neural network of single cells that processes environmental information while sharing resources across its nodes, grows over that text, the original text becomes something new over and over. In the installation, the movement of the microorganism is read in real time by a camera equipped with an AI-based OCR (Optical Character Recognition) software that translates the printed quote to a digital text. The OCR algorithm asserts agency in the remix process, since it can interpret a word with some of its characters omitted as another word or combination of letters, or recognize a partially covered character as another. By capturing errors, the system can insert new characters, rearrange letters and create words that are not in the original text. The new character arrangements and word combinations, through what may at first appear to be an implementation of selective remix through deletion, ${ }^{21}$ also include an additive act that not only inserts new meanings to an appropriated text but creates a novel material semiotic object. Throughout this process, the remixed text is tweeted, with each subsequent tweet abridging the previous one.

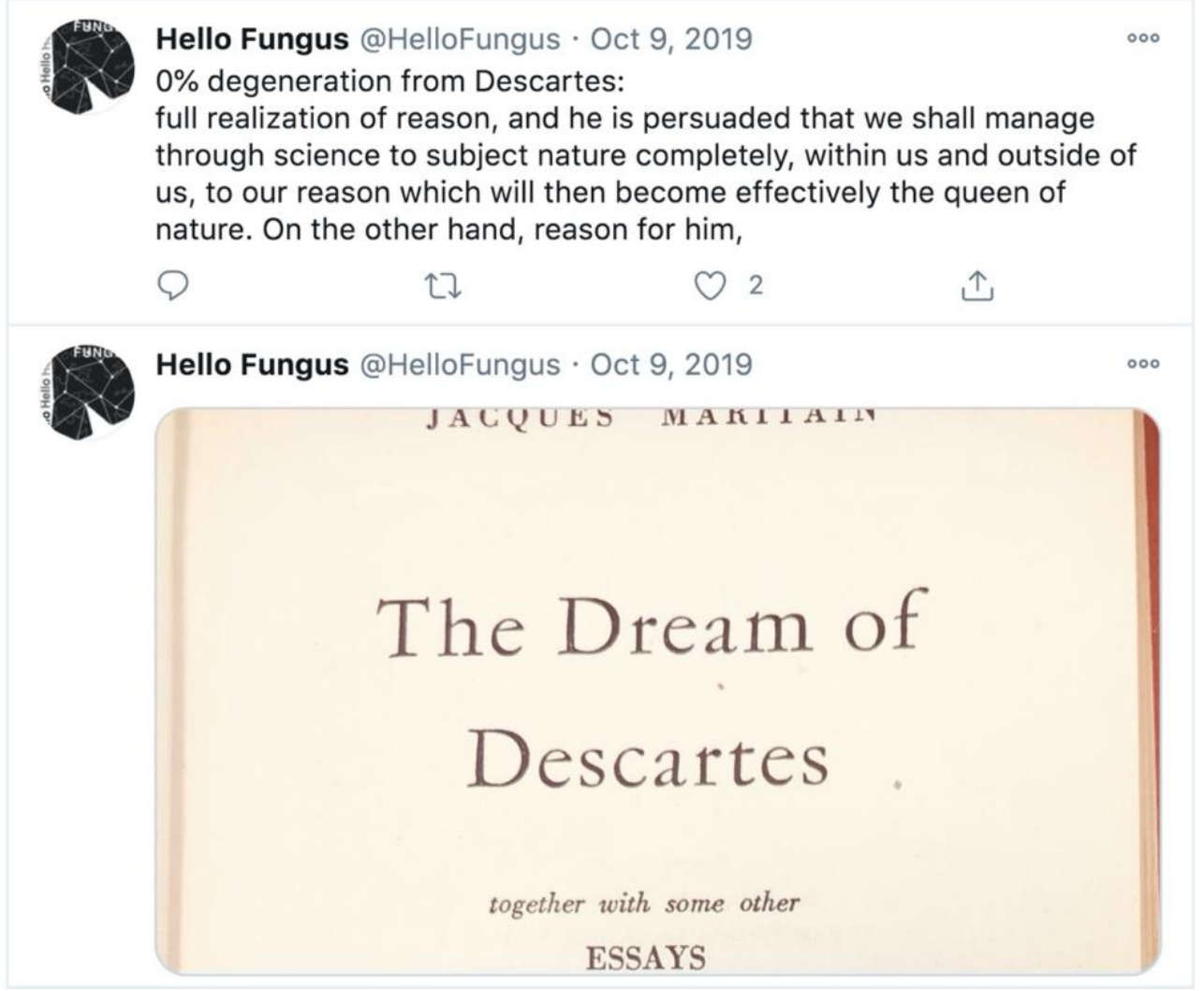

Figure 4. Cesar \& Lois, Degenerative Cultures, Twitter Feed of @HelloFungus, Initial “Reading” of The Dream of Descartes, Singapore Global Digital Art Prize Biennale, 2019. 


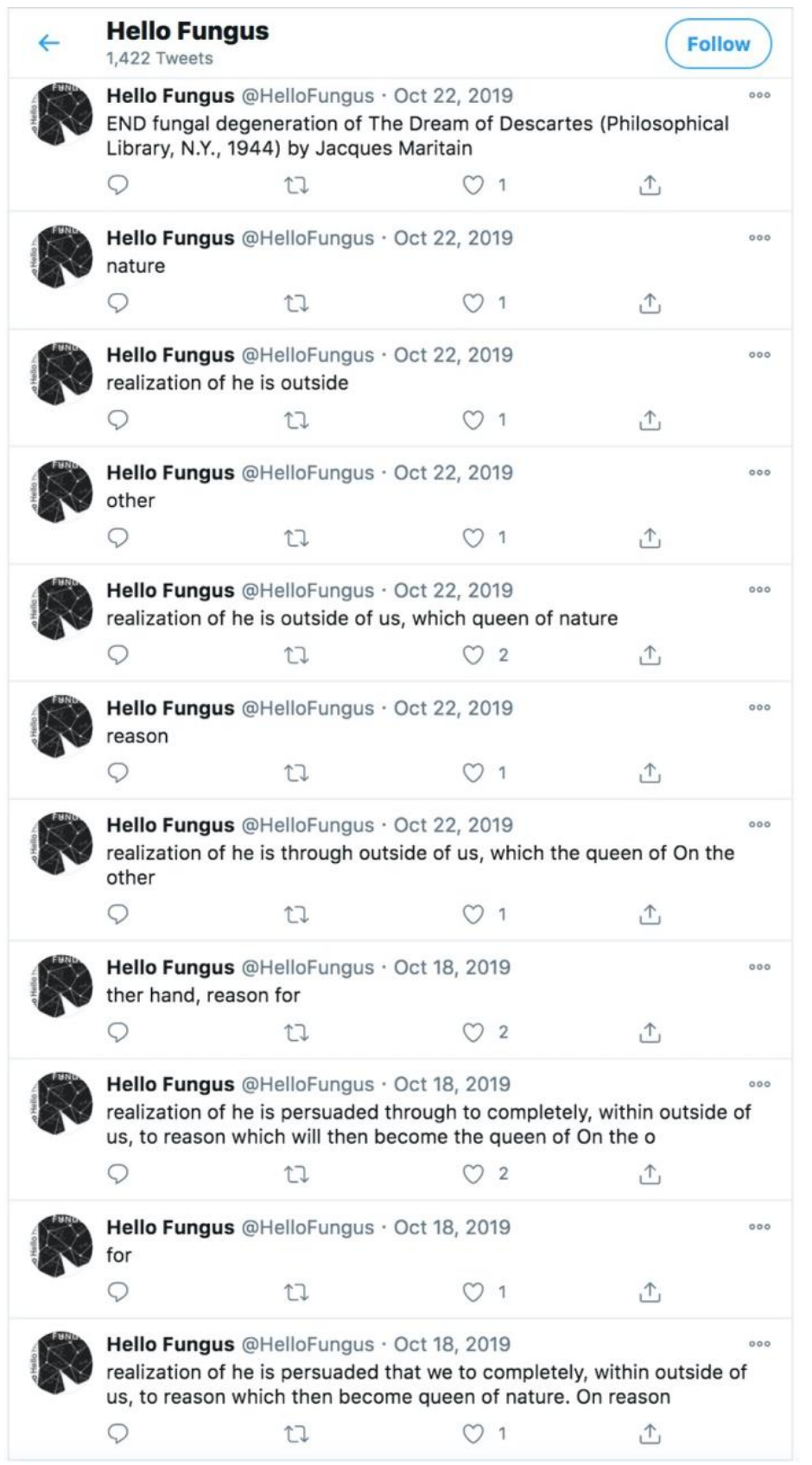

\section{Figure 5. Cesar \& Lois, Degenerative Cultures, Twitter Feed of @HelloFungus, Final Output of The Dream of Descartes, Singapore Global Digital Art Prize Biennale, 2019.}

In "A Poética de uma Inteligência Artificial Microbiológica e um Organismo Inteligente" (The Poetics of a Microbiological AI and an Intelligent Organism), we included excerpts of the Twitter feed as poems, co-authored by Cesar \& Lois together with Physarum polycephalum and 
@ HelloFungus. ${ }^{22}$ In the published versions, each poem's lines reflect the chronological sequencing of the output, so that the first line reflects the original text before the growth of the organism. In this way, the last Tweet of a sequence, which appears at the top of the Twitter feed, becomes the final line of the poem. "The Dream of Descartes, Descartes and Physarum polycephalum" is a partial extract from the action of Physarum polycephalum growing on the book The Dream of Descartes by Jacques Maritain, ${ }^{23}$ captured from Degenerative Cultures: Singapore, between October 18 and 22, 2019.

The Dream of Descartes, Descartes and Physarum polycephalum

full realization of reason, and he is persuaded that we shall manage through science to subject nature completely, within us and outside of us, to our reason which will then become effectively the queen of nature. On the other hand, reason for him

realization of he is persuaded that we through to completely, outside of us, to reason then become the queen of nature. On the oth

er reason for

realization of he is that we through to completely, within outside of us, to reason which then become the queen of On the other ha

nd, reason for

realization of he is persuaded that we to completely, within outside of us, to reason which then become queen of nature. On reason

for

realization of he is persuaded through to completely, within outside of us, to reason which will then become the queen of On the o

ther hand, reason for

realization of he is through outside of us, which the queen of On the other

reason

realization of he is outside of us, which queen of nature

other

realization of he is outside

nature

Figure 6. Cesar \& Lois, Degenerative Cultures Output of The Dream of Descartes As a Poem, Published in "A Poética de uma Inteligência Artificial Microbiológica e um Organismo Inteligente, $" 2020 .^{24}$ 
Cloud-seeding is used to stimulate rain by injecting chemicals into clouds using ... An attempt by South Korea to create artificial rain to tackle air

Clo -s $d \mathrm{~g}$ is $\mathrm{u} d \mathrm{t}$ mulate rai byin $\mathrm{ng}$ emi I i c uds sing A ttempt b

South Korea to creat a i i in ckle air

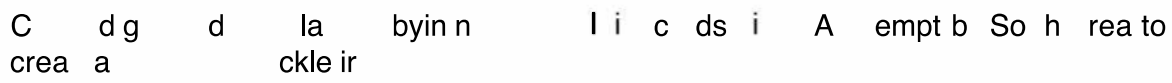

gd I bynn I c ds i A mpt o h ea a

\section{Figure 7. Cesar \& Lois, Degenerative Cultures Output of Digital Fungus Feed As the Poem, “Why Make it Rain?," Published in "A Poética de uma Inteligência Artificial Microbiológica e um Organismo Inteligente, 2020. $^{25}$}

The second poem, "Why Make it Rain?," was created through the intervention of the digital fungus in an Internet text about cloud seeding. Similar to the growth of the living organism over the physical text, the AI plotted the digital text over the screen and consumed individual characters. The source material for the digital fungus relates to the specific environmental context of the location of the installation, which in Singapore includes weather manipulation and artificially induced rain.

Remix principles in this installation include the recontextualization of the philosophical/theoretical text, which is placed alongside digital texts on geoengineering and the environment from scientific journals and newspapers and exhibited in an art context. Current modes of thinking and acting in relation to nature update the modern philosophical foundation that has justified the exploitation of nature. In the different iterations and poetic output of Degenerative Cultures, the modernist anthropogenic ideas expressed in the original text are physically transformed through the actions of digital and biological organisms.

Degenerative Cultures remixes in real time both the quote from the book on display and the Internet texts. In the first moments after the installation, the text of the book is unaltered by the biological organism. In just a few hours after the inoculation of the book, changes in the text can be observed. As the hours and days of the exhibition pass, characters first hidden by the microorganisms can reappear. We observe the movement of the microorganism, as the culture travels in and out of the text, excising letters. The text is altered and words disappear, only to reappear. Similar to a DJ scratching on a vinyl disc, when the original material is reversed and replayed it turns into another thing: it gains a new meaning.

When someone interacts with the installation remotely by Twitter, the Twitter user can monitor the Twitter feed of @HelloFungus, where the original quote and subsequent changes to the text are archived. On site, local participants can witness the altered source and generated text in the live 
printout. However, the Internet text's origin is sometimes obscure, and while it is clear that one is reading a quote, the source is not always apparent.

The Twitter feed, the on-site printout and the digital fungus acting on the screen in the installation, are different outputs of the degenerative process conducted by the artwork and functioning together. Degeneration in this instance does not only degrade but also generates new meanings in the creation of new signs. The original semiotic objects (book and Internet texts) are displaced from their contexts, juxtaposed and reformed in new iterations. The embedded philosophy, geoengineering theory and Renaissance landscape concepts are displaced and updated, generating new semiotic objects, and anyone can watch this live process and observe the changing meaning of the text. Throughout this process one can see the shift in how remix is implemented in Degenerative Cultures, from subtracting and adding characters in order to rebuild the meaning of the texts to a regenerative remix output as texts "that are constantly updated, meaning that they are designed to change according to data flow." 26 If the viewer follows the traces left by the artwork, they will discover a regenerative remix, which adheres to the "principle of periodic change, of constant updates." 27 This is evident in the output of the installation, as the poetry excerpted above reveals, with continually updated textual compositions and constantly shifting characters.

\section{MICROBIOLOGICAL GROWTH: SEARCHING FOR A TRANSSPECIES DEEP REMIX}

As Lev Manovich has stated, digital technology creates a common ground through which all previous media can be easily edited and combined. Elements such as numerical representation, the logic of selection, modularity and transcoding, among others, turn the software-based medium into an appropriate environment for what he calls "deep remixability." 28 As the author explains, although deep remixability is connected to remix culture and concepts, this term has a wider meaning, as it refers not simply to the remixing of different media content, but to the techniques, methods and logics of representation in a movement that he calls "hybrid revolution." 29 As members of an art collective, we ask: What if this concept were extended to biological art practice? This is an important question for us in interrogating our own creative process. In our works, this concept extends further to the integration of digital and biological realms. With its bhiobrid system, Degenerative Cultures creates a transspecies deep remix, mixing the logics of digital technologies, multiple media sources, social networks and biological entities, and outputting something original.

"Nature," in this case microbiology, remixes the philosophical text, but what is created also asserts philosophical concepts. Human readers observe the deconstruction and destruction of humanity's assertion of control over nature, a control that is touted in the classical philosophy texts on display. Perhaps that is another aspect of remix: a resignification of the original is spelled out in an active process of assertion (in this case, the assertion of microbiological growth logic). Through automatic (although not necessarily unintelligent) $)^{30}$ growth, nature "rewrites" the text on humanity's superiority over nature. There is a subversive element in remix that offers revolutionary possibilities for thinking-like a microbiologically oriented AI.

We imagine that this layering of different logic systems - the crossing of human, computerized and microbiological ways of making decisions - offers an opportunity for rethinking our human systems and ultimately remixing society, through substantive, material changes to our technological systems. We propose a radical shift in the logic of AI, and in our human systems that are dependent on artificial decision-making. This creative experiment, which links microbiological 
growth logic to artificial intelligence, is one step in rethinking how human knowledge may become layered, and ultimately corrupted, as the text is grown over and changed, and continues to change, with the original meaning rerouted - a forking of sorts - through integration with nonhuman logic systems, including microbiological and artificial intelligences.

What circuitous pathways in thinking can become possible through a robust rethinking of AI, by the merging of nonliving with microbiological intelligences? We predict that the future multiintelligences that emerge will incorporate the past, articulate pre- and posthuman decision-making, and merge the logic processes from past millennia with machine thinking. In the last century, when Borges wrote of a labyrinthine path that enfolds the past and the future and the stars, could he have anticipated a future multi-intelligence, with the capacity for remixing Borges' own thinking, rethinking a maze of mazes? ${ }^{31}$

\section{THE EPISTEMOLOGICAL REMIX HYPOTHESIS: RETHINKING DUALISTIC DOCTRINES BY MERGING INTELLIGENCES}

This proposal for an integrated intelligence inserts microbiological logic into human systems, presenting a poetic hypothesis for utopian consciousness: an intelligence driven by "nature's" logic that subverts inherited philosophical doctrines. We imagine a remix of modern epistemology with nonhuman logic sourced in microorganisms. In doing so, we consider Amerindian cosmologies that decenter the human perspective. ${ }^{32}$ In our art projects, artificial intelligences and ecologies merge, making possible a rethinking of existing knowledge sets in a remix of modern and ancient, organic (microbiological) and inorganic (AI-driven) knowledge. Those knowledge bases, which extend from a way of life with origins in Western Europe, have led to capitalism and current sociotechnical systems. ${ }^{33}$ Modern epistemology rests on the dichotomies that are inherent in these traditions, such as the divide between Nature and Humanity, and leads to the objectification of living and nonliving parts of the environment. In the anthropocentric perspective of modern societies, a certain concept of the individual (white, male, Christian...) has a privileged hierarchical position relative to other entities, including nonhuman entities: nature as commodity.

As Cesar \& Lois, we identify with a growing cadre of artists who work from a pan-ecological, cross-epistemological perspective. In designing artworks that integrate intelligences sourced at different levels of ecosystems, we have as research references ideas central to the three ecologies of Felix Guattari ${ }^{34}$ and the thousand ecologies of Erick Hörl, ${ }^{35}$ the Amerindian perspectivism of Eduardo Viveiros de Castro ${ }^{36}$ and the multispecies worldings of Donna Haraway. ${ }^{37}$ This article, focused on remix in our practice, does not fully flesh out those ideas. Importantly, however, in mapping a possible future intelligence, we look to the prehuman decision-making processes of microorganisms and to the Amerindian ways of thinking of and relating to the universe as recorded by Ailton Krenak. ${ }^{38}$ Shoshana Zuboff links shifts in democratic power structures to nonconsensual data extraction technologies. ${ }^{39}$ On the other hand, Jason Moore argues that, in the context of global capitalism, "Nature is external and may be coded, quantified, and rationalized to serve economic growth...." Situated in the technological and political paradigms articulated by these scholars, we take a contemplative approach to merging human, artificial and ecological intelligences, and we envision a path in which all intelligences work together on behalf of each of those nodes.

Human beings have reached a number (7.8 billion in 2020) that surpasses our common understanding of the term crowd, and we have rapidly evolved new technologies to communicate, 
organize and even love across great distances. (It is no longer strange to source "love in the telematic embrace," 41 as Roy Ascott insinuated in 1990.) Yet our ability to think as a collective is for the most part represented in movements to maintain separateness, with exceptions in coordinated acts of resistance against social and political inequity or, alternatively, assertions of one group's superiority. Can an intelligence arise that is ecosystemic, that does not fall into the trap of objectivity and adhere to the human exceptionalism of an anthropocentric logic? Through the artworks introduced above, Cesar \& Lois projects a future that integrates human, nonhuman living and non-living entities as viable mappings for technology. In that future, no one (human or otherwise) has singular authority, and in this way, through the forking of logic along multinatural pathways, technological deviations may usher in new realities.

\section{ACKNOWLEDGEMENTS}

In the development of Degenerative Cultures, Cesar \& Lois relied on the research contributions of students and the input of scientists in Brazil and California, including conversations with CSUSM biologist Betsy Read, who first introduced Cesar \& Lois to Physarum polycephalum with a strain originally sourced by her colleague, biologist Tom Wahlund. CSUSM DaTA Lab students and UNICAMP ACTLab student Héllen Anjos worked with Cesar \& Lois on research and development. Reno Beserra and Jeremy Speed Schwartz contributed to the technical development of Degenerative Cultures. The artwork received funding from a CSUSM Research, Scholarship, and Creative Activity Grant and Grant 2018/24452-1, São Paulo Research Foundation (FAPESP).

\section{ENDNOTES}

1. Refer to the article by Wiedmann et al. for a detailing of how affluence correlates with consumption and also with environmental impact.

2. Lucy HG Solomon and Cesar Baio. "An Argument for an Ecosystemic AI: Articulating Connections across Prehuman and Posthuman Intelligences." International Journal of Community Well-Being, 6.

3. Eduardo Navas, Remix Theory: The Aesthetics of Sampling (New York: Springer, 2012).

4. Navas, Remix Theory: The Aesthetics of Sampling, 6.

5. Lev Manovich, The Language of New Media, 1st ed. (Cambridge: The MIT Press, 2000).

6. Lev Manovich, Software Takes Command (New York: Bloomsbury Academic, 2013), 24.

7. Cesar Baio, "O Filósofo Que Gostava de Jogar : O Pensamento Dialógico de Vilém Flusser e a Sua Busca Pela Liberdade," Flusser Studies, no. 15 (2013): 1-11.

8. Vilém Flusser, Into the Universe of Technical Images (Minneapolis: University of Minnesota Press, 2011).

9. Ibid, 125.

10. Manovich, The Language of New Media.

11. Navas, 5.

12. Donna Haraway, Staying with the Trouble: Making Kin in the Chthulucene (Durham: Duke University Press, 2016), 12.

13. Navas, 60.

14. Ibid. 
15. Gilbert Simondon, On the Mode of Existence of Technical Objects (Minneapolis: Univocal Publishing, n.d.).

16. Kembrew McLeod and Rudolf Kuenzli, Cutting Across Media: Appropriation Art, Interventionist Collage, and Copyright Law (Durham: Duke University Press, 2011). 17. "Inceptionism: Going Deeper into Neural Networks," Google AI Blog (blog), accessed October 29, 2020, http://ai.googleblog.com/2015/06/inceptionism-going-deeper-into-neural.html. 18. "Why Is Deep Dream Turning the World into a Doggy Monster Hellscape?," Rhizome, accessed October 29, 2020, http://rhizome.org/editorial/2015/jul/10/deep-dream-doggy-monster/. 19. See: www.thispersondoesnotexist.com.

20. Jacques Maritain, The Dream of Descartes (New York: Philosophical Library, 1944).

21. Navas, Remix Theory: The Aesthetics of Sampling.

22. HG Solomon and Baio, "A Poética de Uma Inteligência Artificial Microbiológica e Um Organismo Inteligente," 243-46.

23. Maritain, The Dream of Descartes.

24. HG Solomon and Baio, "A Poética de Uma Inteligência Artificial Microbiológica e Um Organismo Inteligente," 244.

25. HG Solomon and Baio, 246.

26. Navas, Remix Theory: The Aesthetics of Sampling, 73.

27. Ibid., 76.

28. Lev Manovich, Software Takes Command, 25.

29. Ibid., 110.

30. Steven Shaviro, "Fruit Flies and Slime Molds - The Pinocchio Theory," accessed October 29, 2020, http://www.shaviro.com/Blog/?p=955.

31. Toshiyuki Nakagaki, "Smart Behavior of True Slime Mold in a Labyrinth," Research in Microbiology 152, no. 9 (November 1, 2001): 767-70, https://doi.org/10.1016/S09232508(01)01259-1.

32. Jorge Luis Borges, The Garden of Forking Paths (New York: Grove Press, 1962).

33. Eduardo Viveiros de Castro, "Os Pronomes Cosmológicos e o Perspectivismo Ameríndio," Mana 2, no. 2 (1996): 115-44, https://doi.org/10.1590/s0104-93131996000200005.

34. Félix Guattari, The Three Ecologies (London: Athlone Press, 2000), 27-69.

35. Erich Hörl, "A Thousand Ecologies: The Process of Cyberneticization and General Ecology," in The Whole Earth. California and the Disappearance of the Outside, eds. Diedrich

Diederichsen and Anselm Franke (Berlin: Sternberg Press, 2013), 121-30.

36. Viveiros de Castro, "Os Pronomes Cosmológicos e o Perspectivismo Ameríndio."

37. Donna Haraway, Staying with the Trouble: Making Kin in the Chthulucene.

38. Ailton Krenak, Ideas to Postpone the End of the World (Toronto: Anansi International, 2020).

39. Shoshana Zuboff, "Big Other: Surveillance Capitalism and the Prospects of an Information

Civilization," Journal of Information Technology 30, no. 1 (2015): 75-89,

https://doi.org/10.1057/jit.2015.5.

40. Jason W. Moore, Capitalism in the Web of Life: Ecology and the Accumulation of Capital (London: Verso, 2015), 2.

41. Roy Ascott, "Is There Love in the Telematic Embrace?” Art Journal 49, no. 3 (1990), 241-47.

\section{REFERENCES}

Ascott, Roy. "Is There Love in the Telematic Embrace?” Art Journal 49, no. 3 (1990). 
Borges, Jorge Luis. The Garden of Forking Paths. New York: Grove Press, 1962.

Cesar Baio. "O Filósofo Que Gostava de Jogar : O Pensamento Dialógico de Vilém Flusser e a Sua Busca Pela Liberdade.” Flusser Studies, no. 15 (2013): 1-11.

Flusser, Vilém. Into the Universe of Technical Images. Minneapolis: University of Minnesota Press, 2011.

Guattari, Félix. The Three Ecologies. London: Athlone Press, 2000.

Haraway, Donna. Staying with the Trouble: Making Kin in the Chthulucene. Durham: Duke University Press, 2016.

HG Solomon, Lucy, and Cesar Baio. Physarum polycephalum, and @HelloFungus. “A Poética de Uma Inteligência Artificial Microbiológica e Um Organismo Inteligente.” In Investigação-Experimentação-Criação: Em Arte-Ciência-Tecnologia. Edited by Diogo Marques and Ana Gago. Porto: Publicações Universidade Fernando Pessoa (2020): 24153).

. "An Argument for an Ecosystemic AI: Articulating Connections across Prehuman and Posthuman Intelligences." In International Journal of Community Well-Being (2020): 126.

Hörl, Erich. "A Thousand Ecologies: The Process of Cyberneticization and General Ecology.” In The Whole Earth. California and the Disappearance of the Outside. Edited by Diedrich Diederichsen and Anselm Franke, 121-30. Berlin: Sternberg Press, 2013.

Google AI Blog. "Inceptionism: Going Deeper into Neural Networks.” Accessed October 29, 2020. http://ai.googleblog.com/2015/06/inceptionism-going-deeper-into-neural.html.

Krenak, Ailton. Ideas to Postpone the End of the World. Toronto: Anansi International, 2020.

Manovich, Lev. Software Takes Command. New York: Bloomsbury Academic, 2013.

- The Language of New Media. 1st ed. Cambridge: The MIT Press, 2000.

Maritain, Jacques. The Dream of Descartes. New York: Philosophical Library, 1944.

McLeod, Kembrew, and Rudolf Kuenzli. Cutting Across Media: Appropriation Art, Interventionist Collage, and Copyright Law. Durham: Duke University Press, 2011.

Moore, Jason W. Capitalism in the Web of Life: Ecology and the Accumulation of Capital. London: Verso, 2015.

Nakagaki, Toshiyuki. "Smart Behavior of True Slime Mold in a Labyrinth." Research in Microbiology 152, no. 9 (November 1, 2001): 767-70. https://doi.org/10.1016/S09232508(01)01259-1.

Navas, Eduardo. Remix Theory: The Aesthetics of Sampling. New York: Springer, 2012. 
Shaviro, Steven. "Fruit Flies and Slime Molds - The Pinocchio Theory." Accessed October 29, 2020. http://www.shaviro.com/Blog/?p=955.

Simondon, Gilbert. On the Mode of Existence of Technical Objects. Minneapolis: Univocal Publishing, n.d.

Rhizome. "Why Is Deep Dream Turning the World into a Doggy Monster Hellscape?" Accessed October 29, 2020. http://rhizome.org/editorial/2015/jul/10/deep-dream-doggy-monster/.

Viveiros de Castro, Eduardo. "Os Pronomes Cosmológicos e o Perspectivismo Ameríndio." Mana 2, no. 2 (1996): 115-44. https://doi.org/10.1590/s0104-93131996000200005.

Wiedmann, Thomas, Manfred Lenzen, Lorenz T. Keyßer, and Julia K. Steinberger. "Scientists' Warning on Affluence." Nature Communications 11:3107 (2020): 1-10.

Zuboff, Shoshana. "Big Other: Surveillance Capitalism and the Prospects of an Information Civilization." Journal of Information Technology 30, no. 1 (2015): 75-89. https://doi.org/10.1057/jit.2015.5.

\section{AUTHOR BIO}

Cesar \& Lois integrates natural and technological networks, probing humanity's relationship to nature by advancing intersections between nonliving and living systems. Consisting of Lucy HG Solomon (CA, USA) and Cesar Baio (SP, Brazil), the collective creates bio-digital hybrids and studies the output of nonhuman systems. Cesar \& Lois endeavors to think with nonhuman networks, pondering microbio-logic (based on growth algorithms of microorganisms) while studying how this can inform human logic. Through adventurous interdisciplinarity, the crosscontinental collective questions societal structures that perpetuate global inequities. Merging laboratory and technological spaces, the duo performs microbiological mappings in order to learn from overlapping patterns of human-based knowledge and nature's growth algorithms. Cesar \& Lois exhibits in spaces across oceans, with exhibitions traveling from Ravenna to San Francisco, and actions from Berlin to Durban. Cesar \& Lois received the Lumen Prize in Artificial Intelligence (2018) and were finalists in Singapore's biennial Global Digital Art Prize (2019) and Poland's International Competition for Intermedia Art (2019). The collective was selected as artists in residence at Coalesce Center for Biological Arts (2020) and UC Davis's Hess Laboratory (2021). cesarandlois.org. 